ARTICLE

\title{
Acceptance and resistance to e-learning adoption in developing countries: a literature review*
}

Eduardo Bizzo a

\begin{abstract}
This article aims at understanding how research on acceptance and resistance to e-learning in developing countries is undertaken. To do so, it performs a systematic literature review of articles from 2007 to 2019 . As a result, 44 analyzed studies have shown the evolvement of e-learning acceptance literature in developing countries in the last decade, mainly grounded on the Technology Acceptance Model (TAM) framework, with minor use of Unified Theory of Acceptance and Use of Technology (UTAUT) and critical success factors perspective. None of the reviewed studies used an explicit framework of resistance to adoption. Also, most of the applications of TAM and UTAUT did not explore the specificities of developing countries in the acceptance of e-learning. Furthermore, the review has found a concentration of studies focusing on students, Higher Education, and developing countries with the highest income levels.
\end{abstract}

Keywords: E-leaning; Education; Acceptance; Resistance; Developing countries.

\section{Introduction}

The debacle of the COVID-19 pandemic imposed several challenges to humankind beyond health issues. Worldwide, the pandemic has significantly impacted social and economic life, requiring measures such as quarantine, social distancing, and isolation of infected populations (ANDERSON et al., 2020).

Regarding Education, according to United Nations Educational, Scientific and Cultural Organization - Unesco (2020), around the World, national-wide school

\footnotetext{
* The views and opinions expressed in this article are those of the author and do not necessarily reflect the official policy or position of BNDES and Ebape/FGV. The author is grateful to the reviewer's and Dr. Cláudio Luis Quaresma Daflon's valuable comments.

a Escola Brasileira de Administração Pública e de Empresas da Fundação Getúlio Vargas/Banco Nacional de Desenvolvimento Econômico e Social, Rio de Janeiro, RJ, Brasil.
} 
closures has been impacting the majority of the student population and localized closures are affecting millions of additional learners. In this context, using online tools, such as online live classrooms, online on-demand teaching, TV video learning, and other methods for online teaching could be a successful mechanism to mitigate the impact of the COVID-19 pandemic on Education (ZHOU, et al., 2020).

E-learning is the learning supported by digital electronic tools and media in which the use of Internet technologies provides a wide range of solutions to enhance knowledge and performance (BASAK; WOTTO; BELANGER, 2018). In general, the adoption and integration of Information and Communications Technology (ICT) into teaching and learning environment may provide more opportunities for teachers and students to work better in a globalized digital age, improving the quality of teaching and learning in the classroom (LAWRENCE; TAR, 2018). The application on e-learning may reduce costs, provide advantages for learners (such as its availability anywhere and anytime and ease of use), and allows facilitate interaction (ALMAIAH; ALKHASAWNEH; ALTHUNIBAT, 2020). In a COVID-19 paradigm, e-learning may be a useful instrument to provide Education without physical contact in a classroom.

Regardless of the benefits of e-learning and other ICT applications in Education, their adoption is not automatic. An extensive body of literature has dealt with the factors associated with this issue by focusing on students' and teachers' adoption of technology (SCHERER; SIDDIQ; TONDEUR, 2019). Some of the reasons for the e-learning adoption are students facing technological difficulty, unavailability of technical staff and lack support of facilities, internet connection, reduced interactivity, weak teachers' IT skills and knowledge, teachers' lack of technology acceptance, and lack of infrastructure such as hardware, software, facilities, and network capabilities (ALMAIAH; AL-KHASAWNEH; ALTHUNIBAT, 2020). Consequently, any public policy strategy aiming at implementing e-learning to mitigate the impact of a pandemic should consider the determinants of acceptance of ICT in Education.

However, countries with a higher education gap probably face more difficulties in effectively implementing e-learning due to different culture, context, and readiness (ALMAIAH; AL-KHASAWNEH; ALTHUNIBAT, 2020), requiring a specific analysis lens. As the adoption of e-learning does not have a standard form applicable to any country or region, research from the perspective of developing countries is essential, as it enables the identification of factors for the adoption of e-learning tools (VALENCIA-ARIAS; CHALELA-NAFFAH; BERMÚDEZHERNÁNDEZ, 2019). Specially during the Pandemic, when schools have been putting effort on using e-learning to intermediate distance Education, factors such as lack of skills and practice of teachers, staff, and families besides the scarcity of 
infrastructure may compromise e-learning benefits and even enhance educational inequalities (DIAS; PINTO, 2020) in developing countries.

The perspective of the so-called developing countries is the main focus of both research and practice in the ICT for development - ICT4D field (WALSHAM, 2017). The ICT4D field refers to development thinking and practice addressing the enabling role of ICT on development relation (SEIN et al., 2019).

Grounding on the ICT4D field and on Information System (IS) acceptance and resistance fields, which investigate the determinants of technology acceptance and usage, this article aims at understanding how research on acceptance and resistance to e-learning in developing countries is undertaken. To do so, it performs a systematic literature review of articles from 2007 to 2019. This review considers e-learning as the use of any digital device or system to mediate the learning process. With a strict searching method, it has selected, analyzed, and categorized 44 studies.

In what follows, this article reviews the theoretical background, discussing the technological acceptance and resistance theories, the adoption and usage of e-learning context, and shedding light on how the ICT4D field may approach e-learning adoption. Afterward, it presents the researc methods, followed by the results and discussion of findings. Finally, a conclusion section ends this article.

\section{Theoretical background}

This section presents a discussion of the technology acceptance and resistance theories. Then, it focuses on the adoption and usage of the e-learning context and the ICT4D field approach.

\subsection{Technological Acceptance and Resistance Theories}

At the very beginning of technology entering users' everyday lives, researchers developed theories and models to understand why the technology is accepted or rejected due to the finding that information technology is underutilized in many organizations. (GRANIĆ; MARANGUNIĆ, 2019). ICT usage may emphasize behaviors toward the 'acceptance' of technologies or the 'resistance' to use them in the Information Systems field. In this sense, we can affirm that acceptance and resistance are the two sides of the motivation coin towards IS usage behavior. If acceptance refers to the conditions that motivate individuals to adopt a technology, resistance refers to those factors that motivate individuals to resist its adoption. Hereupon, one can consider acceptance and resistance theories as applications of motivation models to explain the behavioral change. 
The expectancy theory is prominent among motivation models and seems to fit in IS acceptance and resistance approaches. If motivation explains behavioral change, this theory considers that people consciously choose courses of action based upon perceptions, attitudes, and beliefs related to their desires to enhance pleasure and avoid pain (ISAAC; ZERBE; PITT, 2001). Then, the motivation to engage in a behavior (which can be resistance or adoption) is a function of the expectations that an outcome may be attained, and the degree of value placed on an outcome in the person (ISAAC; ZERBE; PITT, 2001). Hence, one feels motivated when three conditions are perceived (ISAAC; ZERBE; PITT, 2001):

- The personal expenditure of effort will result in an acceptable level of performance.

- The performance level achieved will result in a specific outcome for the individual

- The outcome attained is personally valuable.

The following presents IS acceptance and resistance approaches, which deal with individuals' motivation to engage in or avoid, respectively, IS usage behavior.

\subsection{Acceptance}

Since the mid-eighties, researchers have been proposing a plethora of theoretical models to examine technology acceptance and usage, including the Theory of Reasoned Action, the Theory of Planned Behavior, the Model of Personal Computer Utilization, Technology Acceptance Model (TAM), and TAM's extension (such as TAM2, TAM3, and UTAUT) (DWIVEDI et al., 2019; LAI, 2017).

One of the more prominent acceptance models, TAM, is based on the mediating role of perceived ease of use and perceived usefulness in the relationship between systems characteristics (external variables), attitude toward using, and actual system use. According to Davis (1986, p. 21), "external variables encompass all variables not explicitly represented in the model" (i.e., perceived ease of use, perceived usefulness, and usage variables), including "demographic or personality characteristics of the actor, the nature of the particular behavior under consideration, and characteristics of referents." TAM has been widely used to study the adoption of various technologies and has arguably become the most influential theory (GRANIĆ; MARANGUNIĆ, 2019). TAM's prominence is mainly due to its transferability to various contexts and samples, its potential to explain variance in the intention to or actual use of technology, and its simplicity of specification within structural equation modeling frameworks (SCHERER; SIDDIQ; TONDEUR, 2019). 
From its initial design, TAM has received modifications: current attributes of the technology acceptance construct, besides Perceived ease of use and Perceived usefulness, include Attitudes toward technology, Technology self-efficacy, Subjective norms and Facilitating conditions (SCHERER; SIDDIQ; TONDEUR, 2019). To consolidate knowledge from modifications and divergent models derived from TAM, VENKATESH et al. (2003) performed an endeavor of reviewing user acceptance models and formulated the Unified Theory of Acceptance and Use of Technology (UTAUT). The model conveys four core variables (performance expectancy, effort expectancy, social influence, and facilitating conditions) and four moderating variables (gender, age, experience, and voluntariness of use) (VENKATESH et al., 2003).

\subsection{Resistance}

The resistance perspective focuses on explaining why and how individuals resist IS implementations and aims to guide organizations on how to manage employees' perceptions and behaviors related to threats, trust, relationships between actors, and management (LAUMER; ECKHARDT, 2011). Compared to the acceptance theory, much less attention to why individuals resist or reject technologies and which factors inhibit or discourage usage in the IS field (LAUMER; ECKHARDT, 2011).

The resistance literature often suggests that user resistance is a reaction to changes and uncertainty, usually related to loss of power, lack of involvement in the change process, and reluctance to change. Lapointe and Rivard (2005), in their seminal work, indicate five basic and standard primitives (or dimensions) of resistance to IS implementation, at individual and unit levels: resistance behaviors, which may vary, for instance, from neutrality and apathy to extremely engaging in physically destructive behavior; the object of resistance; the perceived threats (by individuals due to the implementation); the initial conditions; and, the subject of resistance.

Kim and Kankanhalli (2009) have also significantly contributed to this literature. They have explained user resistance before a new IS implementation, integrating the technology acceptance and resistance literature with the status quo bias perspective, understanding psychological and decision-making mechanisms underlying the resistance. The resistance literature is more recent and less proliferated than its acceptance pair.

Finally, even though acceptance and resistance to IS have been treated as separate approaches, some researchers have been developing and testing models aiming at integrating them (e.g. ALTHUIZEN; 2018). 


\subsection{Adoption and usage of ICT in Education}

Determinants to the adoption and usage of ICT in Education have been studied over the last years. Among these determinants are training and professional development opportunities, level of technical support, ICT infrastructure, proper curricula, available time, confidence, resistance to change, attitudes, and beliefs (SALAM et al., 2018). It is worth mentioning that these determinants comprehend from individual traits and preferences from a micro perspective to macro conditions, such as national regulations. All these conditions and their interplay matter when studying the ICT usage in Education and its effects.

Within the technology acceptance perspective, many studies in Education have been produced, most of them applying TAM to e-learning (GRANIĆ; MARANGUNIĆ, 2019). According to Granić and Marangunić (2019), TAM and its variations represent a credible model for facilitating the assessment of diverse learning technologies, and its core constructs are robust in learning settings. The TAM's predominance in Education seems not to differ from other sectors. The model is pervasive across sectors and ICT types. Taking the central constructs perceived ease of use and perceived usefulness, it is coherent with expectancy theory to assume that user's perception of how easy it is to use technology and how useful this is in achieving practical goals are relevant on motivating the user to adopt this technology, not only in Education but in all sectors.

Regarding external factors (those excluding perceived ease of use and perceived usefulness), the most used ones in TAM models for e-learning are self-efficacy, subjective norm, enjoyment, computer anxiety, and experience (ABDULLAH; WARD, 2016). Also, these factors seem to matter for individual motivation in general, not only in Education.

Even though TAM is the most-used theory in ICT acceptance research in Education, some studies have used UTAUT as the ground theory (KAYALI; ALAARAJ, 2020). Some studies have applied UTAUT key constructs (performance expectancy; effort expectancy; social influence; and facilitating conditions) to evaluate e-learning adoption, such as the use of interactive whiteboards among teachers (ŠUMAK; ŠORGO, 2016), and the application of social media in research practices (GRUZD; STAVES; WILK, 2012).

Also, some studies approximate resistance perspective, but without necessarily using the IS resistance approach models and even using acceptance perspective elements. Torres, Evans and Schneider (2019) identify institutional-related barriers of institutional culture, faculty self-efficacy, and a lack of institutional support 
as the leading causes of implementation and adoption challenges in Education. Muqtadiroh et al. (2019), on the other hand, propose that perceived threat, perceived usefulness, perceived inequity, and behavior intention are resistance factors to ICT usage in Education.

Retaking the expectancy theory, resistance determinants as uncertainty about technology's value, negative attitude, low self-efficacy, and lack of support are compatible with the constructs of perception of effort needed, performance level, and its outcomes in Education, which explains motivation (in this case, to resist to ICT in Education).

\subsection{ICT4D and e-learning adoption}

The adoption of ICT does not have a standard form that applies to any country or region, which makes research from the perspective of developing countries essential to identify specific factors for the adoption of e-learning tools (VALENCIA-ARIAS; CHALELA-NAFFAH; BERMÚDEZ-HERNÁNDEZ, 2019). In this sense, theories of technology diffusion created in developed countries should observe the context and particularities of developing countries to make sense when applied to them.

The ICT for development (ICT4D) field, which seeks to examine the development changes and its multitude of dimensions in developing countries brought about by the deployment and use of ICT and how it is enabled (SEIN et al., 2019), calls for theorizing in the context of developing countries. Also, this field aims to examine the relationship between the local context and ICT accounting for social, political, and economic issues (DE et al., 2018).

Previous research has already shown ICT failure in developing countries, related to factors such as low level of quality of infrastructure, low availability of ICT skills, complex power structures, and incongruence between the development context and the design and implementation of the ICT (CHIPIDZA; LEIDNER; 2019). As ICT usage in developing countries is more prone to failure due to specific barriers, understanding these determinants is crucial.

\section{Research method}

The review aimed to identify, assess and analyze representative academic literature on acceptance and resistance to e-learning in developing countries. For the review, a literature search was undertaken for one month (from March to April 2020). The following online bibliographic databases were consulted: 
- Publons

- Science Direct

- Google Scholar

The following searching string was adopted:

('Acceptance' OR 'Resistance' OR 'Adoption') AND

('E-learning') AND ('Developing countries' OR

'Developing country')

The following exclusion criteria were applied:

- Studies referring to ICT in Education in general, not strictly related to the use of a digital device or system to mediate the learning process;

- Studies in which the geographical scope was not explicit and studied country was not in the list of developing countries of the United Nations;

- Studies not related to acceptance or resistance.

The search was limited to publications written in English and was not limited to a specific time. The selected literature's title, abstract, and text were screened to ensure adherence to the scope and not meeting exclusion criteria. Qualified publications were retained, lasting 71 for analysis. The following step comprised a detailed process of reading and analyzing the full text of the selected publications. The final selection in this review was composed of 44 studies.

Publications were categorized according to (i) educational stage; (ii) user, (iii) approach (TAM, UTAUT, critical success factor, and others); (iv) country (region and income group); and (v) if studies highlight specificities for developing countries (yes or not). In approach categorization, studies were assigned for TAM or UTAUT, even in cases where the model was the extension or a direct application of the constructs of one (or the two) of them.

\section{Results}

Table 1 in the appendix presents articles per categorization. Studies were about 25 countries, three of them conveying more than one country: Saudi Arabia (5), Pakistan (3), Lebanon (3), Ghana (2), South Africa (2), Jordan (2), Sri Lanka (2), Tanzania (2), Taiwan (2), Libya (2), Malaysia (2), Liberia (1), Thailand (1), Indonesia (1), Brazil (1), United Arab Emirates (1), Iraq (1), Burkina Faso (1), Peru (1), Thailand (1), Qatar (1), Tunisia (1), Colombia (1), Egypt (1), Oman 
(1). As Graph 1 presents, studies on the theme started being published with more frequency in 2011, with a decline in 2018.

Graph 1 - Publications per year

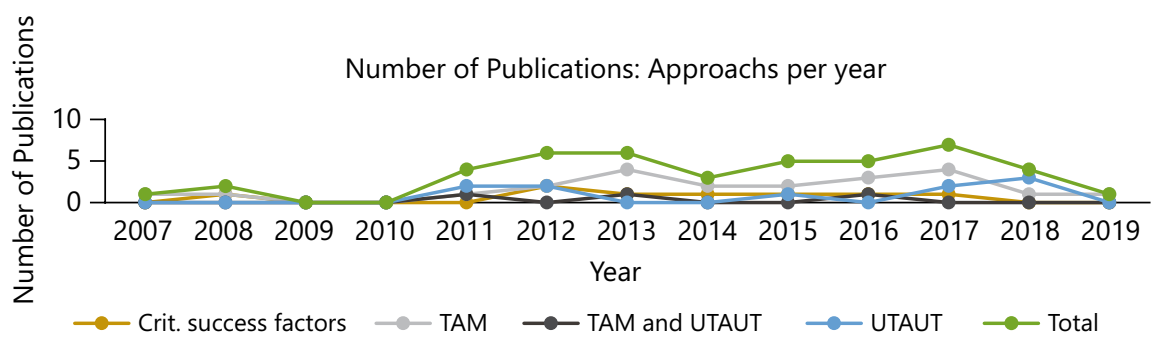

Source: Own elaboration (2021)

Results in Graph 2 show that most studies applied the TAM (or its extensions) framework, followed by UTAUT. Most works on TAM in developing countries follow the general pattern of e-learning acceptance studies, mainly using the TAM framework. Almost 20\% applied a critical success factor perspective, which combines elements from acceptance and resistance. None of the reviewed studies used an explicit framework of resistance to adoption.

Graph 2 - Publications by approach

\section{Approach}

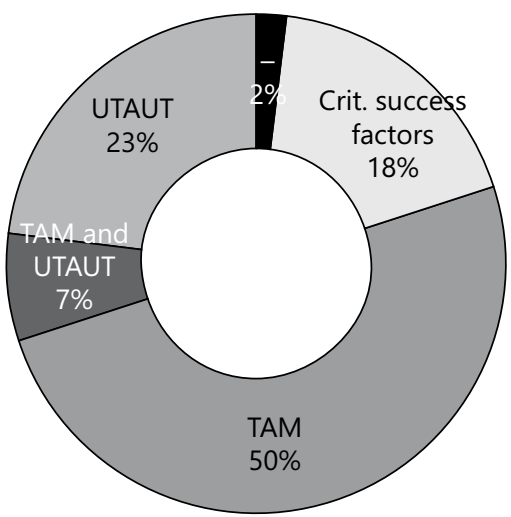

Source: Own elaboration (2021) 
As Graph 3 demonstrates, most of the applications of TAM and UTAUT do not explore the specificities of developing countries in acceptance towards e-learning. By doing so, these studies limit themselves to test if TAM and UTAUT frameworks explain acceptance in developing countries. Although it is vital to test the external validity of these models across countries, not going beyond it reduces TAM and UTAUT's potential to enlighten policy and initiatives to implement e-learning in developing countries. Some exceptions bring exciting insights. Abdel-Wahab (2008) recommends the sequential use of predecessor distance learning technologies from correspondence courses to radio, TV, CDROM, and internet when the infrastructure for e-learning is unavailable. Maldonado et al. (2011) argue that teachers, parents, and peers may influence students to use educational portals in cases of low technology diffusion and awareness in poor regions.

Notwithstanding, research on critical success factors commonly emphasizes developing countries' specificities concerning barriers and determinants of adoption and usage of e-learning. Some of the frequently mentioned critical adoptions are technological infrastructures, including the availability of computers and internet access; ICT-competence among the educational stakeholders and basic technical knowledge and skills; existence of e-learning policy; organization management and social interaction; government support; teachers' resistance to change (BHUASIRI et al., 2012; ESTERHUYSE; SCHOLTZ, 2015; MWAKYUSA; MWALYAGILE, 2016; XAYMOUNGKHOUN et al., 2012).

Graph 3 - Specificities for Developing Countries by approach

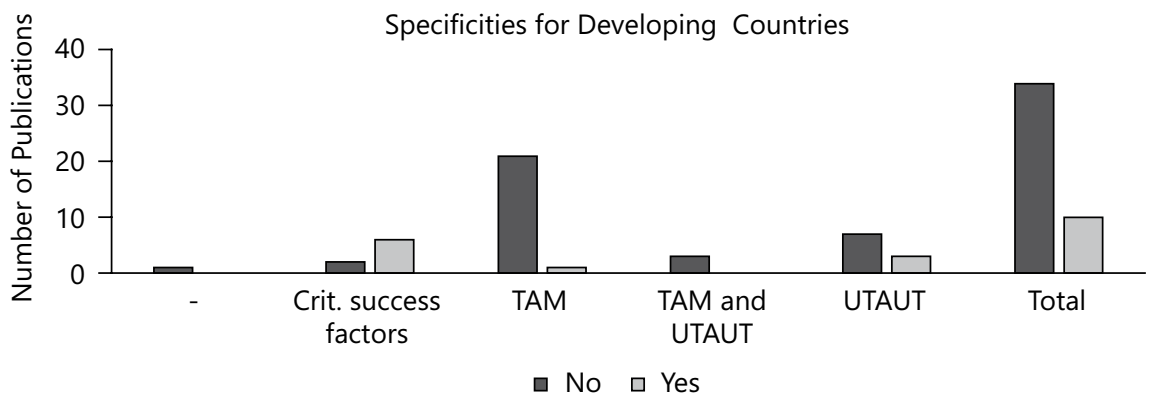

Source: Own elaboration. (2021)

Regarding the users, there is a substantial concentration of studies on students. Only $18 \%$ of the studies focus exclusively on teachers, a portion slightly higher than studies that do not distinguish between users $(16 \%)$. When it comes to the 
educational stage, there is a significant concentration on Higher Education (70\%) in comparison to primary or secondary Education (23\%). Also, most studies analyze countries with higher income levels within the developing countries (upper middle income (43\%) and high income (23\%), while low-income countries respond to only $9 \%$ of the reviewed articles. These information compose Graph 4.

Graph 4 - Publications by User, Educational Stage, Region and Income Group

User

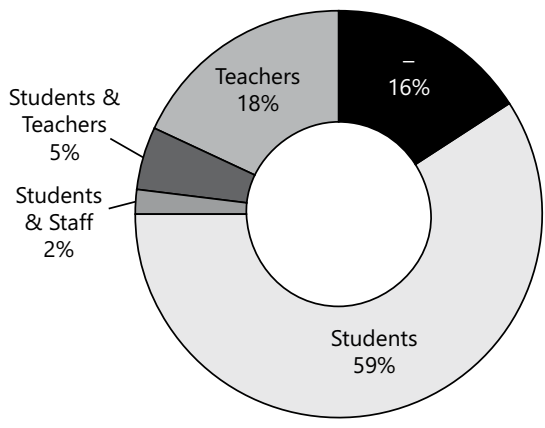

Region

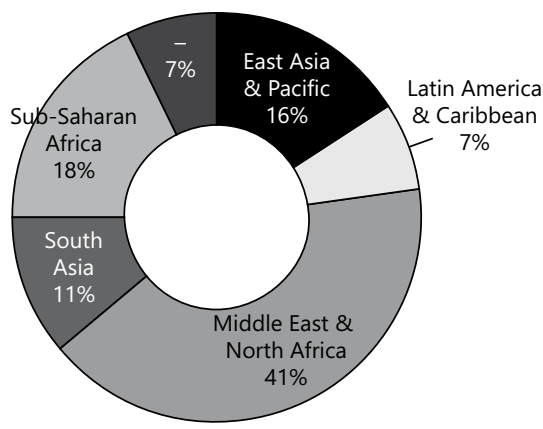

Educational Stage

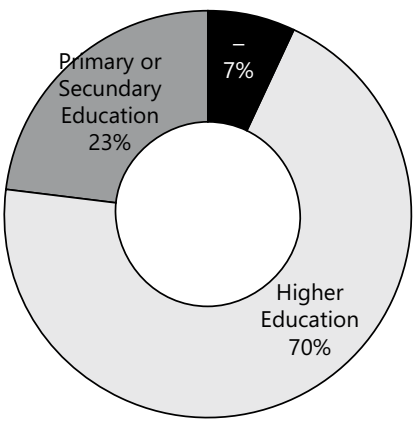

Income Group

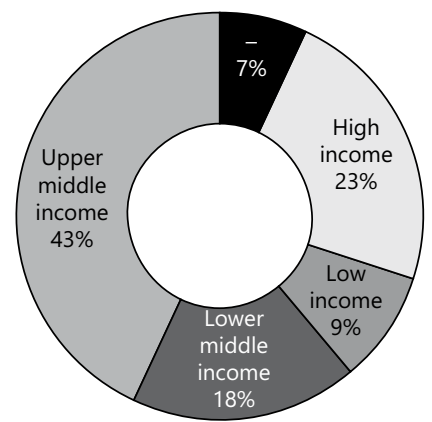

Source: Own elaboration (2021)

\section{Discussion}

Results have shown the evolution of e-learning acceptance literature in developing countries in the last decade, mainly grounded on the TAM framework, with minor use of UTAUT and the critical success factors approach. However, the application 
of TAM and UTAUT models have been principally testing the robustness of the model in developing countries, without delineating which specificities of these countries must be considered to analyze acceptance. Through an ICT4D, which refers to the thinking and practice for the deployment of ICTs in developing countries with development purposes, the acceptance field can build a specific approach for developing countries. Authors such as Abdel-Wahab (2008) and Maldonado et al. (2011) demonstrate that it is possible to conciliate acceptance of consolidated frameworks and the specificities of developing countries.

In sum, although it is valuable and methodological feasible to undertake acceptance analysis on Education ICT in developing countries, most of the literature only evaluates whether it is valid to apply, in the developing countries, models that come from developed ones. However, if humankind is genuinely engaged in building a sustainably developed, it is vital to address each developing country's particularities and challenges, including Education.

Little needs to be said about the centrality of Education in development and its enabling role in different aspects, such as per capita income, long-run growth, gender equality, and health. The United Nations has considered this pivotal role when defined "Quality Education" as a stand-alone Sustainable Development Goal (SDG 4) within the 17 ones as a means of achieving a better and more sustainable future (UN, 2015). The Education goal comprises targets to "ensure inclusive and equitable quality Education and promote lifelong learning opportunities for all."

Inclusiveness, equitability, and opportunities are fundamental and necessary tenets of the quality Education constructs which underlie SDG 4. Each developing country has challenges and contexts to foster ICT usage in Education, effectively improving learning. These challenges and contexts are not only different when compared to developed countries. It also varies within the developing countries.

Then, without understanding and directing policies to the determinants of ICT usage in each developing country, the positive effects of ICT in Education may vary heterogeneously across countries, harming notably those less developed. It would mean that ICT could favor Education quality inequity worldwide, reducing opportunities and excluding most impoverished students and teachers.

Indeed, through the expectancy theory approach, we can conjecture how the challenge of ICT usage is higher in more impoverished schools. For instance, under the lack of infrastructure resources and connectivity, low digital culture and competencies, deficiency in process, and the availability of digital resources, 
students, professors, and staff may be unmotivated to use ICT in the learning process. It would happen because they understand that this use requires high effort (or even it is prohibitive) and that the ICT usage conversion in improved Education performance and outcomes is unreliable. The motivation may be scarce also because their schools have just other primary necessities than promoting ICT usage.

In fact, in multicultural and unequal countries, there are sensitive concerns about the challenges of access to digital artifacts and the articulation of digital learning and curriculum practices (IVENICKI, 2021). In Brazil, for instance, during the pandemic period, most students have not had access to digital learning to attend online courses (IVENICKI, 2021). Also, more than providing internet and infrastructure, lack of competencies, proper methods to insert technologies in a learning context and transferring competencies to virtual settings mediated by e-learning have shown decisive in transform ICT usage in Education outputs in more impoverished contexts during the COVID-19 pandemic period (OLIVEIRA; GOMES; BARCELLOS, 2020; PARREIRA; LEHMANN; OLIVEIRA, 2021).

Further, dealing with ICT usage barriers in developing countries is especially relevant considering the pos-COVID era. Due to the school closures and remote schooling, the learning deficit has harmed everyone, but mainly the least privileged students, who have been facing a more significant burden and which will require all public efforts (DIAS, 2021; GOMES; VÁZQUEZ-JUSTO; COSTA-LOBO, 2021). Besides learning deficits, pos-COVID era requires an imperative effort to recover Education in its multiple ends and goals: supporting educators, students, and families, with a specific focus on the underprivileged, counting on the participation of the social forces of community and society (GOMES; VÁZQUEZ-JUSTO; COSTA-LOBO, 2021).

E-learning usage will be a helpful tool within hybrid or on-site classes since the barriers are identified and tackled. The use of ICT in recent experiences has shown promising results in the developing world, mixing remote and on-site learning in the class return. (CASTIONI et al., 2021). ICT may be helpful since it comes with political, economic, and pedagogical conditions to empowering technological languages that facilitate dialogic teaching methods (HABOWSKI; CONTE; JACOBI, 2020).

Regarding the focus identified in the e-learning ICT usage in developing countries, the concentration of research on Higher Education seems not to dialogue with the primary educational challenges of developing countries: broadening 
access to Education and enhancing quality Education (KREMER; BRANNEN; GLENNERSTER, 2013). These challenges are in line with the "Quality Education" UN's Sustainable Development Goal, and directly related to its target 4.1 ("By 2030 , ensure that all girls and boys complete free, equitable and quality primary and secondary Education leading to relevant and effective learning outcomes") (UN, 2015). For e-learning acceptance literature to contribute to educational needs in developing countries, it is also vital to address analyses on basic Education. Additionally, the concentration on students restricts the analysis of the role of other essential stakeholders in e-learning adoption, such as teachers, principals, staff, and families.

Furthermore, the review has found a concentration of research on high and upper-middle-income countries. Most of the researchers of acceptance and resistance to e-learning within the developing countries are neglecting those countries with, comparatively, more barriers to the adoption of e-learning and higher educational needs.

\section{Conclusion}

This article, which aimed at reviewing the literature on acceptance and resistance to e-learning in developing countries, has selected, analyzed, and categorized 44 studies according to the following types (i) educational stage; (ii) user, (iii) approach (TAM, UTAUT, critical success factor, and others); (iv) country (region and income group); and (v) if studies highlight specificities for developing countries (yes or not).

Results have shown the evolvement of e-learning acceptance literature in developing countries in the last decade, mainly grounded on TAM Framework, with minor use of UTAUT and critical success factors perspective, which combines elements from acceptance and resistance. None of the reviewed studies used an explicit framework of resistance to adoption. Most of the applications of TAM and UTAUT do not explore the specificities of developing countries in the acceptance of e-learning. Consequently, its contribution reduced to build a theory of particularities of developing countries on this issue.

As the SDG agenda posits, the contribution of Education in building a sustainably developed world requires addressing inclusiveness, equitability, and opportunities in Education across all countries. For ICT usage to work as an inclusive and equitable tool to quality Education, it should provide equal opportunities in all schools. Doing that is only possible if researchers identify barriers and determinants for educational ICT usage in local contexts. 
Indeed, some critical adoption factors in developing countries have already been found, such as technological infrastructures, ICT competence, basic technical knowledge and skills, lack of e-learning policy, and government support. It indicates that, in a COVID-19 paradigm in which the diffusion of e-learning could mitigate the impact of school closure, it is fundamental to design strategies and policies considering the specificities and particularities of developing countries.

Furthermore, the review has found a concentration of studies focusing on students, Higher Education, and countries with high levels of income between the developing countries. Then, the following gaps should be addressed by researchers to contribute to thinking and practice aiming at tackling the educational challenges in these countries with the contribution of e-learning: exploring the specificities of developing countries when applying consolidated acceptance frameworks; encompassing primary and secondary educational stages and all the relevant stakeholders of the adoption of e-learning in the analyses; and covering countries with lower levels of income.

Finally, from the results and discussion, the following gaps in e-learning acceptance and resistance in developing countries should be addressed by researchers:

- Exploring the specificities of developing countries when applying consolidated acceptance frameworks.

- Encompassing primary and secondary educational stages and all the relevant stakeholders of the adoption of e-learning in the analyses.

- Covering countries with lower levels of income.

Besides these gaps, further work on acceptance and resistance in e-learning could consider using explicitly resistance frameworks. Therefore, they could disentangle tools and systems of e-learning and its relationship with acceptance and resistance, and also account for regional inequalities within each studied country. 


\section{Aceitação e resistência à adoção de e-learning em países em desenvolvimento: uma revisão de literatura}

\section{Resumo}

Esse artigo tem como objetivo compreender como as pesquisas em aceitação e resistência ao e-learning em países em desenvolvimento são realizadas. Para isso, realiza uma revisão sistemática da literatura de artigos de 2007 a 2019. Como resultado, 44 estudos analisados mostraram a evolução da literatura de aceitação de e-learning em países em desenvolvimento na última década, principalmente com base no Modelo de Aceitação de Tecnologia (TAM), sendo observado um menor uso das abordagens de Teoria Unificada de Aceitação e Uso de Tecnologia (Utaut) e de fatores críticos de sucesso. Nenhum dos estudos usou uma estrutura explícita de resistência à adoção. Além disso, a maioria das aplicações do TAM e UTAUT não explorou as especificidades dos países em desenvolvimento na aceitação ao e-learning. Encontrou-se uma concentração de estudos com foco em alunos, Ensino Superior e países com altos níveis de renda entre os em desenvolvimento.

Palavras-chave: E-learning. Educação. Aceitação. Resistência. Países em desenvolvimento.

\section{Aceptación y a la adopción del e-learning en los países en desarrollo: una revisión de la literatura}

\section{Resumen}

Este artículo tiene como objetivo comprender cómo se lleva a cabo la investigación sobre la aceptación y la resistencia al e-learning en los países en desarrollo. Para ello, realiza una revisión sistemática de la literatura de los artículos de 2007 a 2019. Como resultado, 44 estudios analizados han mostrado la evolución de la literatura de aceptación del e-learning en los países en desarrollo en la última década, basada principalmente en el Modelo de Aceptación de Tecnología ( TAM), con un uso menor de la Teoría Unificada de Aceptación y Uso de Tecnología (UTAUT) y perspectiva de factores críticos de éxito. Ninguno de los estudios utilizó un marco explícito de resistencia a la adopción. Además, la mayoría de las aplicaciones de TAM y UTAUT no exploró las especificidades de los países en desarrollo en la aceptación del e-learning. También, la revisión ha encontrado una concentración de estudios centrados en estudiantes, Educación Superior y países en desarrollo con los niveles de ingresos más altos.

Palabras clave: E-learning. Educación. Aceptación. Resistencia. Países en vía de desarrollo. 


\section{References}

ABDEL-WAHAB, A. G. Modeling students' intention to adopt e-learning: a case from Egypt. The Electronic Journal of Information Systems in Developing Countries, [s. 1.], v. 34, n. 1, p. 1-13, 2008. https://doi.org/10.1002/j.1681-4835.2008.tb00232.x

ABDULLAH, F.; WARD, R. Developing a General Extended Technology Acceptance Model for E-Learning (GETAMEL) by analysing commonly used external factors. Computers in Human Behavior, New York, v. 56, p. 238-256, Mar. 2016. https://doi.org/10.1016/j.chb.2015.11.036

ALMAIAH, M. A.; AL-KHASAWNEH, A.; ALTHUNIBAT, A. Exploring the critical challenges and factors influencing the E-learning system usage during COVID-19 pandemic. Education and Information Technologies, Dublin, v. 25, p. 5261-5280, May 2020. https://doi.org/10.1007/s10639-020-10219-y

ALTHUIZEN, A. Using structural technology acceptance models to segment intended users of a new technology: propositions and an empirical illustration. Information Systems Journal, [s. 1.], v. 28, n. 5, p. 879-904, Dec. 2018. https://doi.org/10.1111/isj.12172

ANDERSON, R. M., et al. How will country-based mitigation measures influence the course of the COVID-19 epidemic? The Lancet, London, v. 395, n. 10228, p. 931-934, Mar. 2020.

BASAK, S. K.; WOTTO, M.; BELANGER, P. E-learning, m-learning and d-learning: conceptual definition and comparative analysis.

E-Learning and Digital Media, [s. 1.], v. 15, n. 4, p. 191-216, Jul. 2018. https://doi.org/10.1177/2042753018785180

BHUASIRI, W., et al. Critical success factors for e-learning in developing countries: A comparative analysis between ICT experts and faculty. Computers \& Education, New York, v. 58, n. 2, p. 843-855, Feb. 2012. https://doi.org/10.1016/j.compedu.2011.10.010

CASTIONI, R., et al. Universidades federais na pandemia da Covid-19: acesso discente à internet e ensino remoto emergencial. Ensaio: Avaliação e Políticas Públicas em Educação, Rio de Janeiro, v. 29, n. 111, p. 399-419, abr.jun. 2021. https://doi.org/10.1590/S0104-40362021002903108

CHIPIDZA, W.; LEIDNER, D. A review of the ICT-enabled development literature: Towards a power parity theory of ICT4D. The Journal of Strategic Information Systems, [s. 1.], v. 28, n. 2, p. 145-174, June 2019. https://doi.org/10.1016/j.jsis.2019.01.002 
DAVIS, F. A technology acceptance model for empirically testing new end-user information systems: theory and results. Thesis (Doctor). Cambridge: Massachusetts Institute of Technology, 1986.

DE, R., et al. ICT4D research: a call for a strong critical approach. Information Technology for Development, London, v. 24, n. 1, p. 63-94, 2018. https://doi.org/10.1080/02681102.2017.1286284

DIAS, E. A educação, a pandemia e a sociedade do cansaço. Ensaio: Avaliação e Políticas Públicas em Educação, Rio de Janeiro, v. 29, n. 112, p. 565-573, jul./set. 2021. https://doi.org/10.1590/S0104-40362021002901120001

DIAS, E.; PINTO, F.C. F. A educação e a Covid-19. Ensaio: Avaliação e Políticas Públicas em Educação, Rio de Janeiro, v. 28, n. 108, p. 545-554, jul./set. 2020. https://doi.org/10.1590/s0104-40362019002801080001

DWIVEDI, Y. K., et al. Re-examining the unified theory of acceptance and use of technology (UTAUT): towards a revised theoretical model. Information Systems Frontiers, New York, v. 21, n. 3, p. 719-734, June 2019. https://doi.org/10.1007/s10796-017-9774-y

ESTERHUYSE, M.; SCHOLTZ, B. Barriers to e-learning in a developing country: an explorative study. In: IDIA CONFERENCE, 9., [s. 1.], 2015. Proceedings[...]. Bengaluru: IDIA, 2015.

GOMES, C.; VÁZQUEZ-JUSTO, E.; COSTA-LOBO, C. Education during and after the pandemics. Ensaio: Avaliação e Políticas Públicas em Educação, Rio de Janeiro, v. 29, n. 112, p. 574-594, jul./set. 2021. https://doi.org/10.1590/S0104-40362021002903296

GRANIĆ, A.; MARANGUNIĆ, N. Technology acceptance model in educational context: a systematic literature review. British Journal of Educational Technology, 2019. https://doi.org/10.1111/bjet.12864

GRUZD, A.; STAVES, K.; WILK, A. Connected scholars: examining the role of social media in research practices of faculty using the UTAUT model. Computers in Human Behavior, New York, v. 28, n. 6, p. 2340-2350, Nov. 2012. https://doi.org/10.1016/j.chb.2012.07.004

HABOWSKI, A.; CONTE, E.; JACOBI, D. Interlocuções e discursos de legitimação em EaD. Ensaio: Avaliação e Políticas Públicas em Educação, Rio de Janeiro, v. 28, n. 106, p. 178-197, jan./mar. 2020. https://doi.org/10.1590/S0104-40362019002701365 
ISAAC, R.; ZERBE, W.; PITT, D. Leadership and motivation: the effective application of expectancy theory. Journal of Managerial Issues, Pittsburg, v. 13, n. 2, p. 212-226, Summer 2001.

IVENICKI, A. Digital lifelong learning and higher education: multicultural strengths and challenges in pandemic times. Ensaio: Avaliação e Políticas Públicas em Educação, Rio de Janeiro, v. 29, n. 111, p. 360-377, abr.jun. 2021. https://doi.org/10.1590/S0104-403620210002903043

KAYALI, M. H.; ALAARAJ, S. Adoption of cloud based E-learning in developing countries: a combination a of DOI, TAM and UTAUT. International Journal of Contemporary Management and Information Technology, Selangor, v. 1, n. 1, p. 1-7, Nov. 2020.

KIM, H. W.; KANKANHALLI, A. Investigating user resistance to information systems implementation: a status quo bias perspective. MIS Quarterly, [s. 1.], v. 33, n. 3, p. 567-582, Sep. 2009. https://doi.org/10.2307/20650309

KREMER, M.; BRANNEN, C.; GLENNERSTER, R. The challenge of education and learning in the developing world. Science, Washington, v. 340, n. 6130, p. $297-$ 300, Apr. 2013. https://doi.org/10.1126/science. 1235350

LAI, P. C. The literature review of technology adoption models and theories for the novelty technology. JISTEM - Journal of Information Systems and Technology Management, São Paulo, v. 14, n. 1, p. 21-38, Apr. 2017. https://doi.org/10.4301/S1807-17752017000100002

LAPOINTE, L.; RIVARD, S. A multilevel model of resistance to information technology implementation. MIS Quarterly, Minneapolis, v. 29, n. 3, p. 461-491, Sep. 2005. https://doi.org/10.2307/25148692

LAUMER, S.; ECKHARDT, A. Why do people reject technologies: a review of user resistance theories. In: DWIVEDI, Y. K.; WADE, M. R.; SCHNEBERGER, S. L. Information systems theory. New York: Springer, 2011. (ISIS, v. 28). p. 63-86.

LAWRENCE, J. E.; TAR, U. A. Factors that influence teachers' adoption and integration of ICT in teaching/learning process. Educational Media International, [s. 1.], v. 55, n. 1, p. 79-105, 2018. https://doi.org/10.1080/09523987.2018.1439712

MALDONADO, U. P. T., et al. E-learning motivation and educational portal acceptance in developing countries. Online Information Review, Bingley, v. 35, n. 1, p. 66-85, 2011. https://doi.org/10.1108/14684521111113597 
MUQTADIROH, F. A., et al. Analysis of user resistance towards adopting e-learning. Procedia Computer Science, [s. 1.], v. 161, p. 123-132, 2019. https://doi.org/10.1016/j.procs.2019.11.107

MWAKYUSA, W. P.; MWALYAGILE, N. V. Impediments of e-learning adoption in higher learning institutions of Tanzania: an empirical review. Journal of Education and Practice, [s. 1.], v. 7, n. 30, p. 152-160, 2016.

OLIVEIRA, J.; GOMES, M.; BARCELLOS, T. A Covid-19 e a volta às aulas: ouvindo as evidências. Ensaio: Avaliação e Politicas Públicas em Educação, Rio de Janeiro, v. 28, n. 108. p. 555-578. 2020. https://doi.org/10.1590/S0104-40362020002802885

PARREIRA, A.; LEHMANN, L.; OLIVEIRA, M. O desafio das tecnologias de inteligência artificial na Educação: percepção e avaliação dos professores. Ensaio: Avaliação e Políticas Públicas em Educação [online]. [Cited in 2021 Sept. 10]. Available from: https://doi.org/10.1590/S0104-40362020002803115. Epub 2021 Feb. 22. ISSN 1809-4465. https://doi.org/10.1590/S0104-40362020002803115.

SALAM, S., et al. Impediments to the integration of ICT in public schools of contemporary societies: a review of literature. Journal of Information Processing Systems, Seoul, v. 14, n. 1, p. 252-269, Feb. 2018. https://doi.org/10.3745/JIPS.04.0062

SCHERER, R.; SIDDIQ, F.; TONDEUR, J. The technology acceptance model (TAM): a meta-analytic structural equation modeling approach to explaining teachers' adoption of digital technology in education. Computers \& Education, New York, v. 128, p. 13-35, Jan. 2019. https://doi.org/10.1016/j.compedu.2018.09.009

SEIN, M. K., et al. A holistic perspective on the theoretical foundations for ICT4D research. Information Technology for Development, London, v. 25, n. 1, p. 7-25, 2019. https://doi.org/10.1080/02681102.2018.1503589

ŠUMAK, B.; ŠORGO, A. The acceptance and use of interactive whiteboards among teachers: Differences in UTAUT determinants between pre-and post-adopters. Computers in Human Behavior, London, v. 64, p. 602-620, Nov. 2016. https://doi.org/10.1016/j.chb.2016.07.037

TORRES, I.; EVANS, J.; SCHNEIDER, M. Faculty resistance to technology integration. In: SOCIETY FOR INFORMATION TECHNOLOGY \& TEACHER EDUCATION INTERNATIONAL CONFERENCE, 2019, Las Vegas.

Proceedings[...]. Las Vegas: Association for the Advancement of Computing in Education, 2019. p. 175-177. 
UNITED NATIONS - UN. General Assembly. Transforming our world: the 2030 Agenda for Sustainable Development. New York, 2015. Available at: https://www. un.org/ga/search/view_doc.asp?symbol=A/RES/70/1\&Lang=E. Cited 2019 Apr. 23.

UNESCO. COVID-19. Educational disruption and response. Paris, 2020. Available at: https://en.unesco.org/covid19/educationresponse. Cited 2020 Apr. 20

VALENCIA-ARIAS, A.; CHALELA-NAFFAH, S.; BERMÚDEZ-HERNÁNDEZ, $\mathrm{J}$. A proposed model of e-learning tools acceptance among university students in developing countries. Education and Information Technologies, Drordrecht, v. 24, n. 2, p. 1057-1071, 2019. https://doi.org/10.1007/s10639-018-9815-2

VENKATESH, V., et al. User acceptance of information technology: toward a unified view. MIS Quarterly, [s. .], v. 27, n 3, p. 425-478, Sep. 2003. https://doi.org/10.2307/30036540

WALSHAM, G. ICT4D research: reflections on history and future agenda. Information Technology for Development, Abinddon, v. 23, n. 1, p. 18-41, 2017. https://doi.org/10.1080/02681102.2016.1246406

XAYMOUNGKHOUN, O., et al. The critical success factors of e-learning in developing countries. Kasetsart Journal - Social Sciences, Korea, v. 33, n. 2, p. 321332, May 2012.

ZHOU, L.; et al. 'School's Out, But Class' On', The largest online education in the world today: taking China's practical exploration during the COVID-19 epidemic prevention and control as an example. Best Evidenence of Chinese Education, [s. 1.], v. 4, n. 2, p. 501-519, Mar. 2020. https://doi.org/10.2139/ssrn.3555520

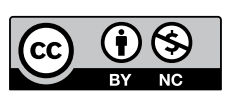

\section{Information about author}

Eduardo Bizzo: Ph. D. candidate, Escola Brasileira de Administração Pública e de Empresas da Fundação Getúlio Vargas. Manager, Banco Nacional de Desenvolvimento Econômico e Social. Contact: ebizzo@gmail.com

iD https://orcid.org/0000-0003-2059-2173 


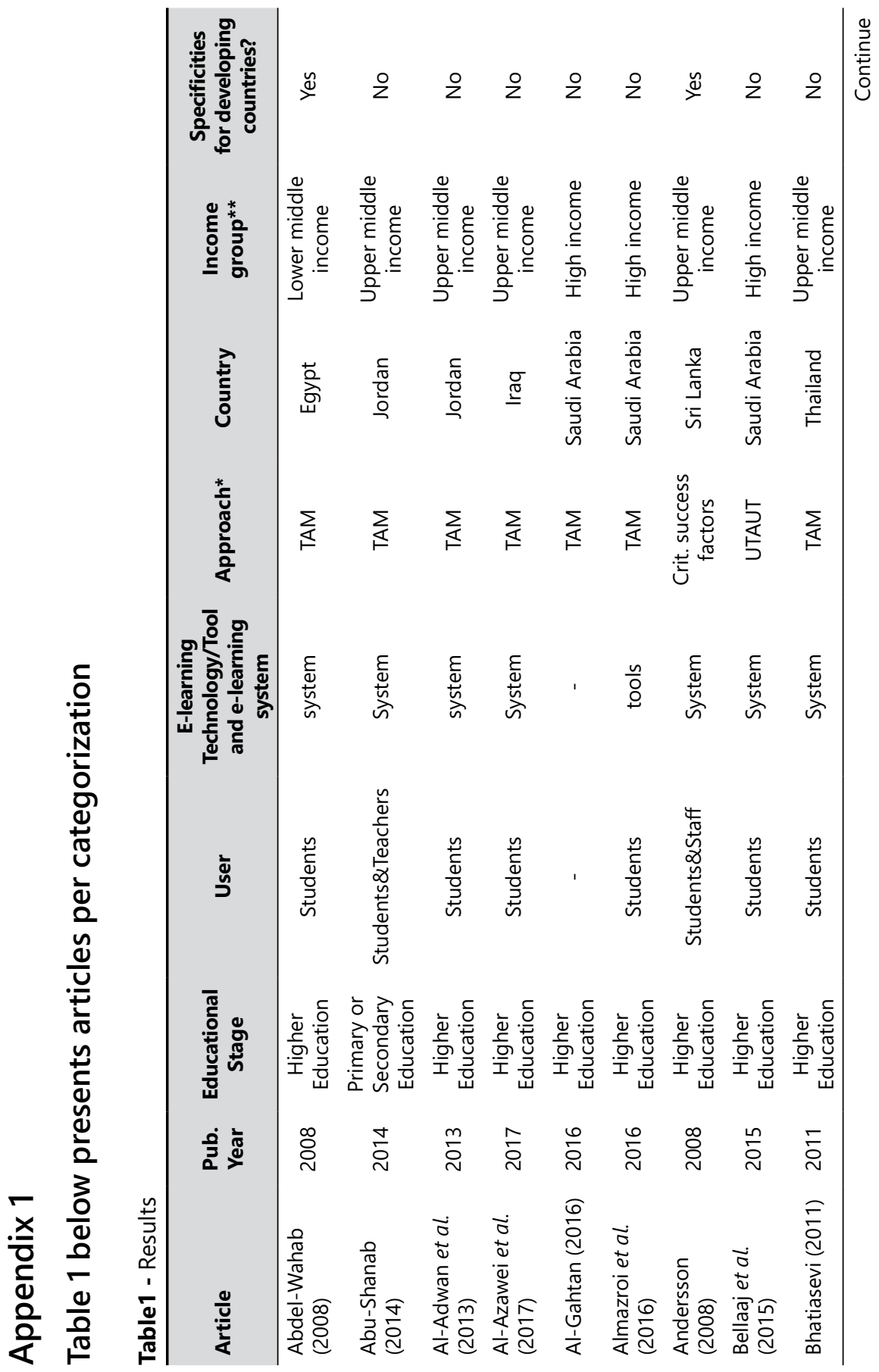




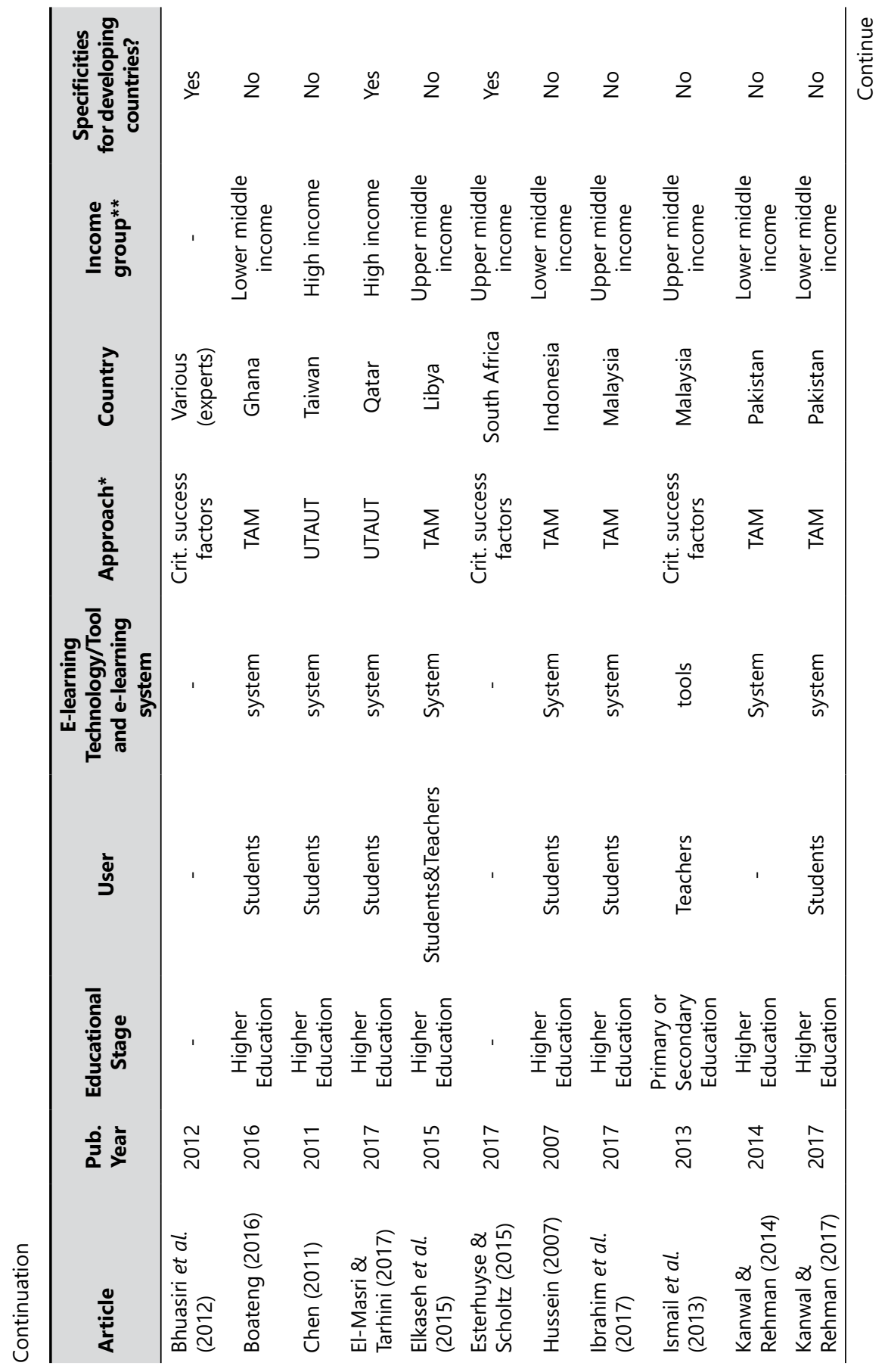




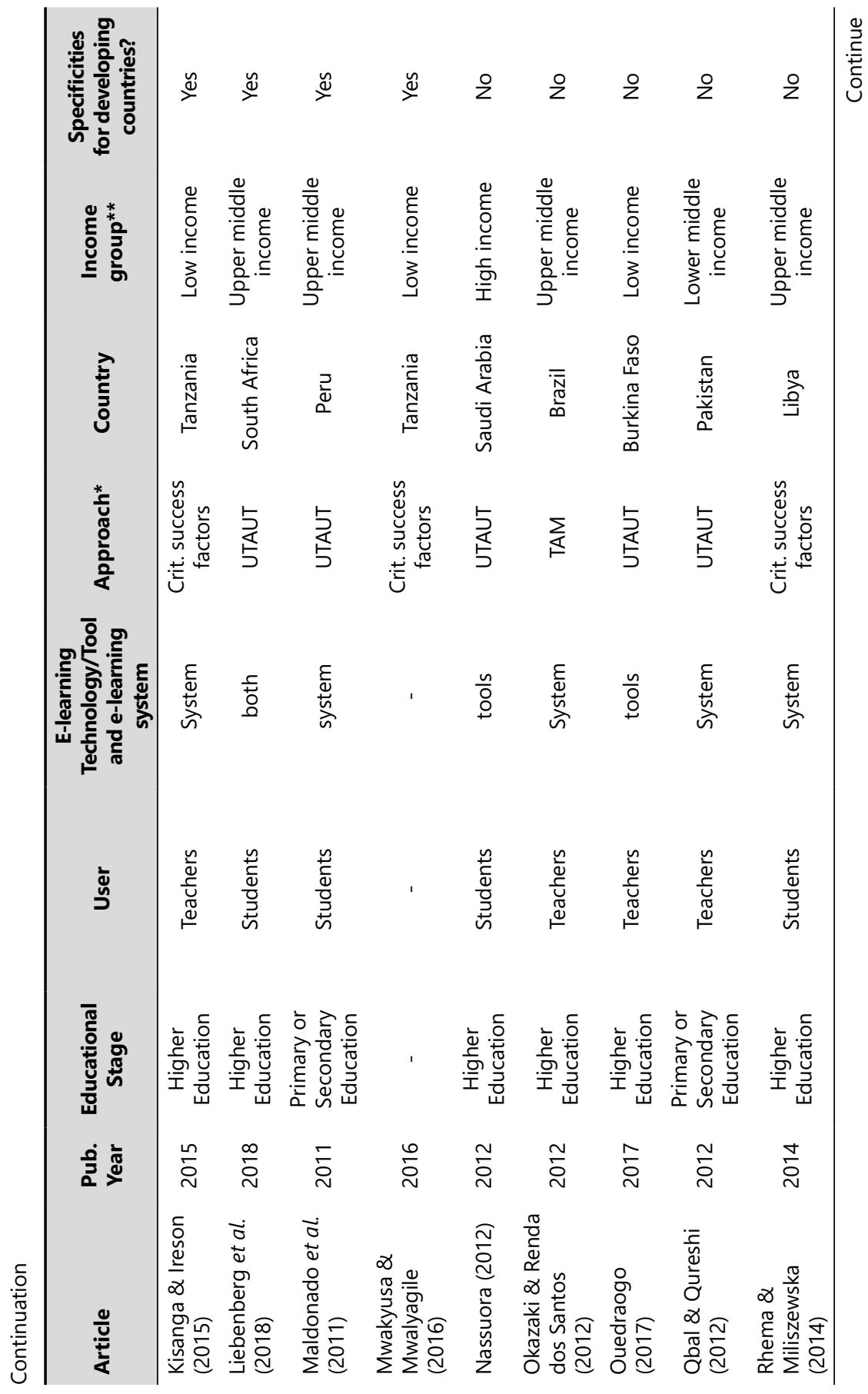




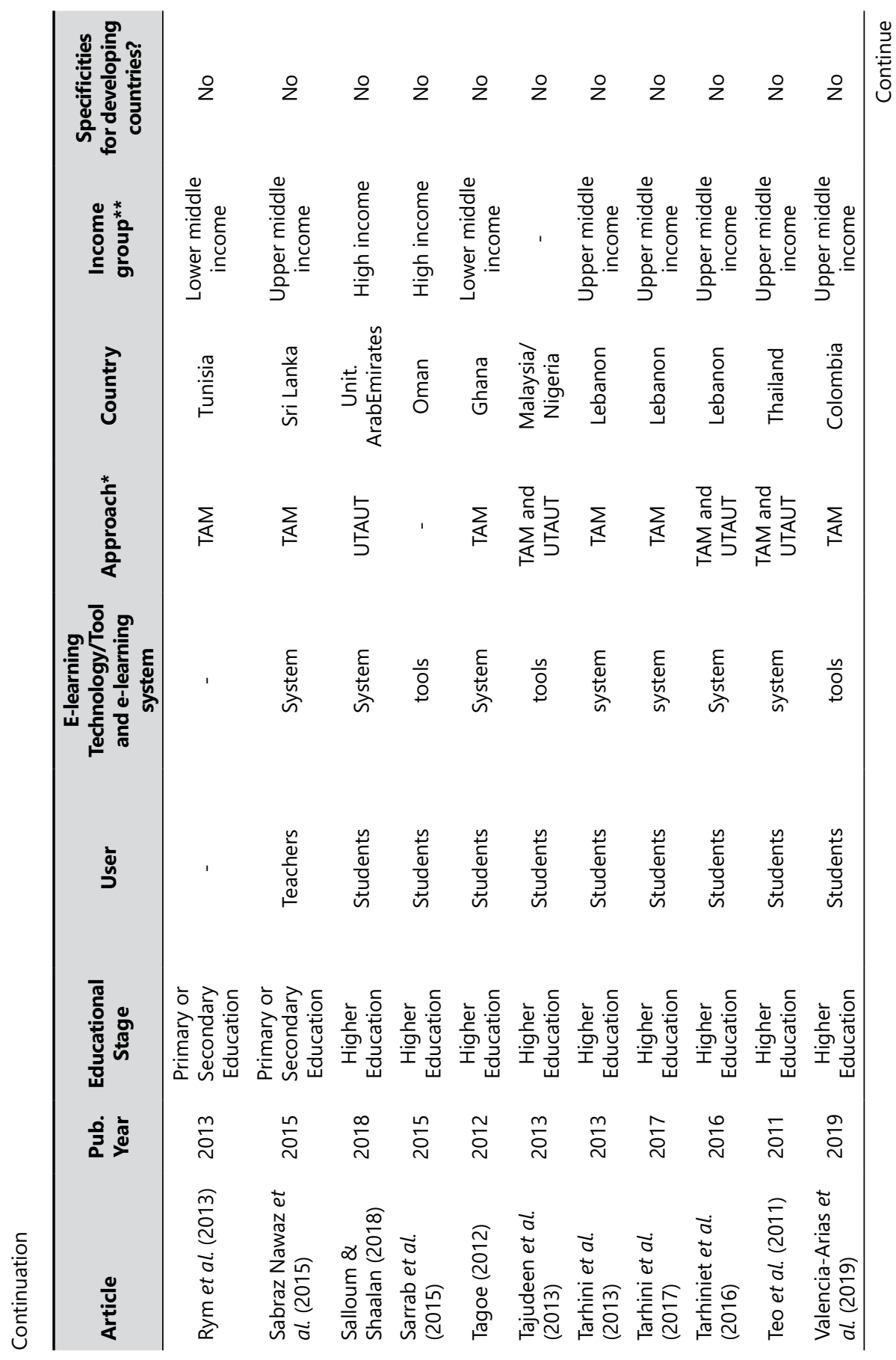




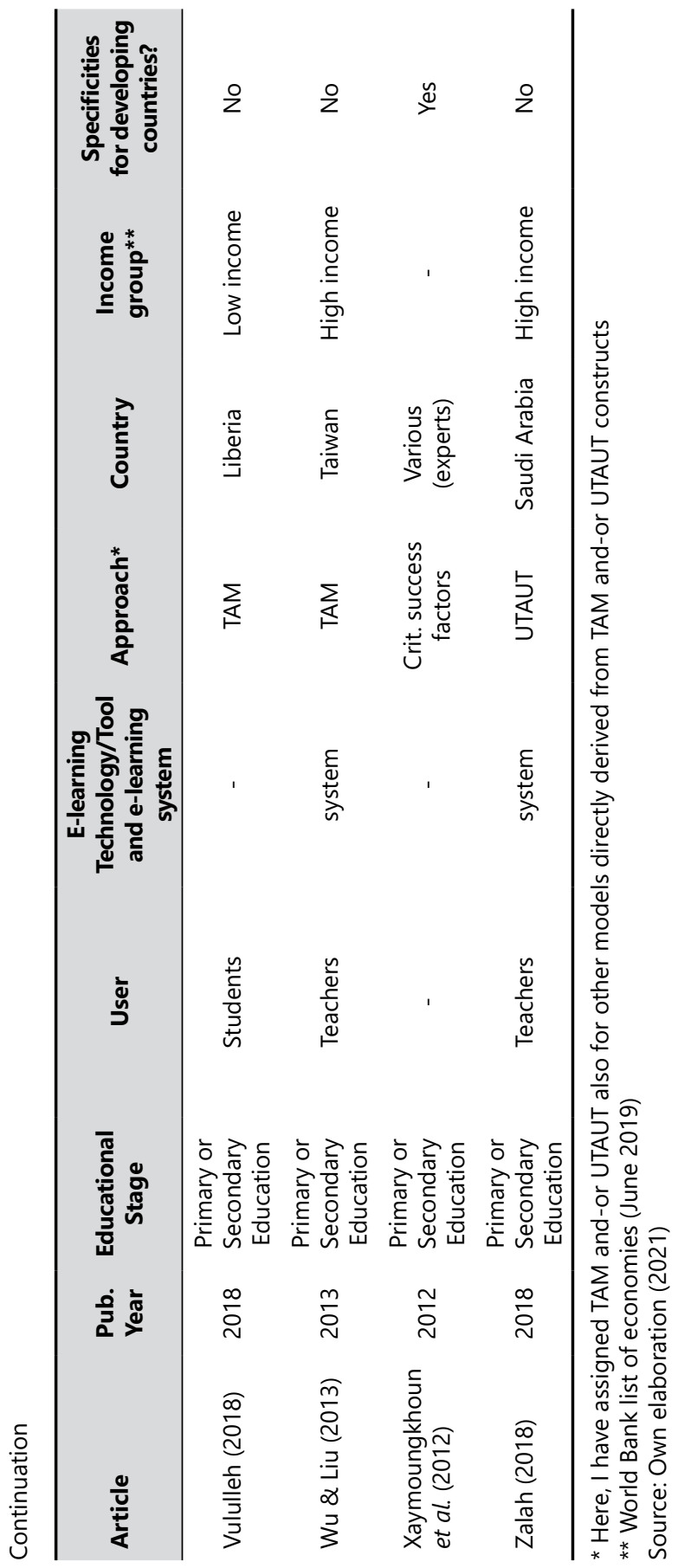

